\title{
MADRASAH
}

Jurnal Pendidikan dan Pembelajaran Dasar

p ISSN: 1979-5599 | e ISSN: 2502-194X

P a g e

169

\section{THE INSIGHTS OF GLOCALIZATION IN ISLAMIC PRIMARY EDUCATION}

\author{
Dewi Nur Suci ${ }^{1}$, Intan Nuyulis Naeni Puspitasari ${ }^{2}$ \\ 1;2Sekolah Tinggi Agama Islam Negeri (STAIN) Kediri, Indonesia \\ 1dewinursuci@gmail.com, 2binta.khoiri@gmail.com
}

\begin{abstract}
The expansion of internationalization has challenged education advancement in 21th century which is not only at Islamic higher education level but also at the Islamic primary education sphere. For preparing young learners to engage in the dynamics of internationalization, some Islamic primary schools competitively share new horizons on integrating sciences, humanism and spiritual values that adapt salaf models of pesantren and global ideas. Therefore, this article, in a qualitative research, exemplifies the social phenomena on how to construct new paradigm of glocalization for the evolvement and perpetuation of Islamic primary educational institution in Indonesia. Collected by observations, interviews and documentations, it is concluded that glocalization can be employed as the panacea for society's needs in which local wisdom can take its portions in curriculum that inserts multiple intelligence and Higher Order Thinking Skill (HOTS) and provide academic agendas of primary instructional classroom.
\end{abstract}

Keyword: Glocalization; Global Skill; Pesantren; Islamic primary education Copyright (C) 2017 Madrasah Jurnal Pendidikan dan Pembelajaran Dasar. All Right Reserved

\section{A. INTRODUCTION}

The recent social problems in globalization that arrest children in young age, the youth or even adults such as bullying, rape, drugs, conflict among teacher, students and parents in the court, and other societal opaque prove that Indonesia is seriously attacked by moral degradation. This condition shows that young generations need educational nutrients to boost their positive personality and shape their noble characters. As a sustainable effort, government has provided rights for the educational institutions to build the institutions which establish curriculum that is appropriate with the need of the students and schools. One of which can be traced from the government's regulations about internationally standardized schools, firstly known as RSBI/ SBI.

The first emergence of SBI and RSBI as the strategic way to create internationalization in Indonesia unpredictably invited long polemics because the word "international" was interpreted as the one that can cause loss of national identity as Indonesian. It is because of the formula of "international" and the implementation of learning and teaching that were considered less-nationalism and lack of patriotism. Those are shown by the first establishment of SBI/ RSBI mostly reflecting western culture like the optimization of international language rather than national language in almost all lessons, the school management which needs more budgets from parents insinuating capitalism, social gaps between the high class and middle class students and others that could lead to westernization culture or very urban citizen. As a result of this condition, governments have issued a local wisdom for Indonesia education in all levels either primary or secondary.

Vol. 9 No. 2, Juni 2017

Madrasah homepage: http://ejournal.uin-malang.ac.id/index.php/madrasah/index 
The local wisdom is a means of sterilization to avoid becoming dominated mentally, intellectually and culturally by forces which are foreign to the traditional of Indonesian figures. Local wisdom is basic knowledge gained from living in balance with nature that is related to culture in the community which is accumulated and passed on (Mungmachon, 2012). This wisdom can be both abstract and concrete, but the important characteristics are that it comes from experiences or truth gained from life. The wisdom from real experiences integrates the body, the spirit and the environment. The local wisdom that is not leaving the globalization spirit or vice versa is now popularized by the term "glocalization," referring to the merger of global and local perspectives on the socio-economic and political impact of all phenomena that affect local and global communities. According to Patel \& Lynch (2013), the terms glocal and glocalization are not new and have mainly been associated with the business, technology, and sociology disciplines.

Glocalized learning and teaching refer to the curricula consideration and pedagogical framing of local and global community connectedness in relation to social responsibility, justice and sustainability (Patel \& Lynch, 2013). Boyd's (2006) and Khondker's (2004) argue that glocalization is a good description of blending and connecting local and global contexts while maintaining the significant contributions of the different cultural communities and contexts. Therefore, the perspectives of glocalization are necessary to be instilled to the Indonesian generations since at their primary educational level. It is because childhood is a golden age and a means of growing up (Clarke, 2002). Additionally, French (2007) states that all children with their inextricable beliefs, backgrounds and cultures are unique individuals who have rights to be treated with respects, positive regard and dignity.

In accordance with the competence of the young learners through glocalization, teachers' professional developments essentially need improving. This is aimed at fulfilling the learners' needs and boosting the teachers' global competence in teaching. Teachers are not only teaching and transferring knowledge. In wider context of glocalization, teachers' performances are evaluated by sister school for the purpose of upgrading knowledge in internationalization realm (Kozin, Greenberg, William, Niehaus, Jacobson, 2011; Wang \& Ho, 2012). Put simply, establishing sister schools in abroad can objectively succeed to construct teacher's global competences. It can be seen by the finding of Kozin, Greenberg, William, Niehaus, Jacobson (2011) finding the failure of teacher education to cope with global competence due to the culture of teacher education that has tended to be local, rooted in neighborhood schools, rather than global.

Due to the importance of glocalization, this paper is intended to investigate the practice of integration of localization and globalization in Islamic primary education, particularly Islamic International School (IIS), located in Grogol-Kediri. IIS Kediri was purposively selected as this school has been pioneered by tremendous pesantren in Indonesia. Pesantren is one of many forms of educational Islamic institutions centering for the spread of Islam and contributing to the ongoing Indonesian education system with a strong hold in the hearts of communities (Zakaria, 2010). Some previous research on the topic of glocalization have been done. Khondker (2004) investigated glocalization as globalization in Japan education, Patel \& Lynnch (2013) analyzed glocalization as an alternative to internationalization in higher education and Mungmachon (2012) observed glocalization for education by scrutinizing the combination of local wisdom and knowledge to face globalization. However, the previous research are different from the foci of this paper because those did not meticulously emphasize on Islamic norms as an inseparable part of localization in the midst of global world. Besides, this paper also provides an

Vol. 9 No. 2, Juni 2017

Madrasah homepage: http://ejournal.uin-malang.ac.id/index.php/madrasah/index 


\section{MADRASAH}

Jurnal Pendidikan dan Pembelajaran Dasar

p ISSN: 1979-5599 | e ISSN: 2502-194X

P a g e

analysis on both students and teachers to deepen the practice of glocalization at IIS as Islamic primary education that is outspoken to name itself an international school.

\section{Review of Related Literature}

Internationalization and glocalization are two related terms in globalization era. Although periods of colonialism have long gone by, Indonesia's dependence on Western educational knowledge remains apparent through discourses of westernization (often spelt out as globalization and internationalization) Kuswandono et al (2011). de Wit (2002) categorizes the most often cited reasons for why internationalization is important to postsecondary education into four groups such as economic, political, academic, and social/cultural. It is stated that economic rationales encompass both the potential career benefits to students and the income that can be generated for the institution through, for example, the recruitment of international students and the establishment of satellite campuses abroad. Political reasons, especially in the years since September 11, are related to matters of national security and foreign policy. Academic rationales for internationalization are usually tied to the missions of liberal education in the age of globalization and accordingly stress world-mindedness and global, critical thinking skills. Finally, sociocultural motivations emphasize skills for intercultural communication

Accordingly, the education system must need a right panacea for the learning and teaching to increase their study and output. It is necessary to find a bridge that can balance the search of understanding global knowledge and local knowledge. This term can be known as glocalization. Based on Patel and Lynch (2012), glocal and glocalization refer to the merger of global and local perspectives on the socio-economic and political impact of all phenomenon that affects local and global communities. Additionally, Boyd's (2006) and Khondker's (2004) in Patel and Lynch (2012) opine that glocalization is a good description of blending and connecting local and global contexts while maintaining the significant contributions of the different cultural communities and contexts.

The terms glocal and glocalization are not new and have mainly been associated with the business, technology, and sociology disciplines. In media discourse, one of the glocalization products is Bollywood movie that has come a long way in the last two centuries. Bollywood has emerged as a more intense interplay between the global and the local which took place during the 1990s that has made progress in all four aspects of globalization, (i.e., goods/services, capital, technology and people (Pillania, 2012). In other words, glocalization is a process whereby a product or service is specifically adapted by each locality or culture in which it occurs. It describes new outcomes of local conditions towards global pressures.

Patel and Lynch (2012) argue glocalization is underpinned by the notion of third culture building in which culturally different communities draw on their strength to form a respectful, engaging, and inspiring third culture space. The third culture space is where diverse cultural communities meet and make connections through dialogue, negotiation, and meaningful engagement. Third culture building supports global community building which endorses the integration of acceptable cultural norms and values in a meaningful and respectful way (Patel et al., 2011). In educational context, glocalization enhances the pedagogical impact of learning beyond cultural relativism and moves the dialogue toward a deeper level of respectful engagement among cultures that also rejects ethnocentrism that has long promoted the dominant worldview of judging other cultural communities through the parochial, tinted lens of one's own cultural standpoint (Patel and Lynch, 2012).

Vol. 9 No. 2, Juni 2017

Madrasah homepage: http://ejournal.uin-malang.ac.id/index.php/madrasah/index 
In contrast to ethnocentric norms that favor the dominant worldview, glocalization embraces various perspective worldview. It focuses on the positive contributions and the beneficial attributes of participating cultures, without imposition on and threat to cultural values and beliefs. Glocalization favors Welikala's (2011) notion of the multi perspective curriculum to represent the curriculum in the 21st century universities. In challenging and rejecting cultural relativist and ethnocentric perspectives, glocalization forces learners and teachers to level the playing field on the basis of mutual respect and shared responsibility and accountability for actions and non-actions that cause impact on local and global societies as a whole (Patel and Lynch, 2012). This means that local and global realities are confronted to encounter the world in relation to individual and collective sustainable futures.

For educational institutions, it is now vital to respond to the phenomena of globalization and internationalization so they may be integrated into the curricula. This step is necessary in order to prepare college and university students to meet future career needs or to become informed globalized citizens. Carnoy (2005) expresses that globalization has substantial impact on knowledge formation especially the knowledge that is provided by and then correlated to higher levels of education. To be truly globalized, Blackmore (1999) states localization is a valid response as the aspects of what constitutes global and local should be viewed as different characteristics of the same phenomenon. In relation to the effects of the globalization phenomena on educational concepts, Schröttner (2010) expresses that both the volume and the speed of global flow have intensified the entanglement of the local and the global, thus many local developments have enormous global consequences and vice versa.

Douglass (2005) claims that although the trends of globalization located within instructional technologies create new markets and force a reform in higher education, all globalization is in fact subject to local (or national and regional) influences. He suggests that in order to have a better understanding of the complexity of globalization toward the future of higher education, institutions should analyze the rapid growth of market needs and the strength and weakness of each institute to make certain changes for finding its individual niche or to broaden its services in order to survive.

Regarding globalization and localization in an educational context, Luk-Fong (2005) and Tong \& Cheung (2011) suggest taking Robertson's (1995) notion of 'glolocalization', a term which combines 'global' with 'localization', into account. Glolocalization presents the twin relationships that may occur between globalization and localization, and it is a way for progressive advancement to occur thus enhancing the quality of life. Glocalisation (or, glocalization), as explained on the Wikipedia website, is a portmanteau of globalization and localization. By definition, the term "glocal" refers to those individuals, groups, divisions, units, organizations, and communities which are willing and able to think globally and act locally (Tien \& Talley, 2012).

The appearance of two separate curricula (i.e. Eastern and Western) in place of one integrated guidance curriculum seems to reflect a desire to identify one's own unique characteristics as reflected in the process of glocalisation (Tien \& Talley, 2012). Luk-Fong (2005) in (Tien \& Talley, 2012) suggests that while applying the integrated curriculum, the students' emotional feelings, mental processes, and individual behaviors must also be taken into account. Nevertheless, the example of mixes of globalization and localization in curriculum development, as provided by Luk-Fong, best offer a theoretical framework for facilitating the actual implementation of the guidance/ moral/ civic education curriculum in Hong Kong as a response to globalization.

Vol. 9 No. 2, Juni 2017

Madrasah homepage: http://ejournal.uin-malang.ac.id/index.php/madrasah/index 


\section{MADRASAH}

Jurnal Pendidikan dan Pembelajaran Dasar

p ISSN: 1979-5599 | e ISSN: 2502-194X

P a g e

\section{B. RESEARCH METHOD}

This research centers on descriptive qualitative by exemplifying the social phenomenon on Islamic primary education, known as glocalization in Islamic International School (IIS). This school was the branch of IIS located in Magetan-East Java Indonesia that is pioneered by Dahlan Iskan, Indonesian minister. This object was purposively selected due to the vision and mission of the school and the management of the school which tend to combine the values of pesantren and modern aspects of education that are necessary for students' needs. Not only seen from the noble goal, IIS fully respects the researchers by welcoming them to trace the worth data related to the issue of glocalization.

The data of this research were gathered by using observations and depth-interviews with the principal, teachers and teaching staffs. Those were ethically conducted to find out the perceptions of the principal, teachers and teaching staffs about the issues of globalization and localization in the elementary school instructions on natural and social science, religion, and culture. The researchers also recorded the hands on activities of the students inside and outside the classrooms. In other words, the researchers were passive participants and treated the phenomenon naturally without any interfere in the process of learning and teaching. To gain deeper understandings on the implementations of curriculum, teaching practices, the use language and other supporting academic activities like memorizing al-Qur'an, enriching Javanese and English vocabulary, building leadership, fostering math-science applications, how to love environment and others.

\section{FINDINGS}

1. Glocalization: Incorporating Local Wisdom and Global Competence for Students To accommodate the localization and globalization ideas for achieving internationalization, Islamic International School (IIS) has incorporated local wisdom and global knowledge on their curriculum. This can be perceived from the educational components of curriculum, teaching method, media, facilities, and language in instructional process and outside the instruction. Those can be elaborated below:

a. School Management and Curriculum

The growth of Islamic International School (IIS) Kediri which has been pioneered from Sabilul Muttaqien pesantren is developed through four formal institutions, including:

1) Foundation of Sabilul Muttaqien pesantren (YPSM). This foundation was built before the reformation era in Indonesia in which the tradition of pesantren remains strong. If analyzed, this foundation has internalized the Nahdlatul úlama (NU) values that embeds the instructional values in pesantren. Pesantren has a lot of posivite values in students' (santri) daily life or even their future goals. Pesantren in common has visions and missions that foster morality towards their God and communal. Those are not only taught by turats or classical books but also by the attitude in social interaction. The teaching and learning in pesantren are usually conducted by the grand teacher (kyai), teacher (ustadz/ustadzah) and student (santri) that are culturally bound up with the local norms of politeness. Most of learning materials are prepared to make students understand the insights of Islam through the lessons of tauhid, figh or aqeedah akhlaq.

2) Department of Education and Culture. Although IIS is a private school, this school follows the curriculum that has been well-arranged by the Department of Education and Culture (Kemendikbud) of Indonesia. This school implements the learning and teaching by using curriculum-13 (K-13) that is recommended in some regions in

Vol. 9 No. 2, Juni 2017

Madrasah homepage: http://ejournal.uin-malang.ac.id/index.php/madrasah/index 
Indonesia by the government. In other words, IIS has implemented the national curriculum in the learning and teaching activities. This is useful because the students can be accepted wherever they want to pursue their study in other higher schools in Indonesia because they are in en educational grades that are legalized by the government.

3) Madrasah Irsyad al-Islamiyah Singapore. This is the madrasah that has become the sister school of IIS. This school has implemented the Cambridge curriculum that is considered as international curriculum. This school is responsible for the progress of IIS. Therefore, IIS has been periodically supervised and trained by the madrasah Irsyad al-Islamiyah Singapore. The teachers are required to follow the English proficiency test known as TOEFL. This is used to balance the teachers' understandings between the content science and the international language in instructional classrooms.

4) Education supervision of in the levels of kindergarten, elementary school, junior high school and senior high school which are bound up with Memorandum of Understanding (MoU). The supervision is very important to sustainably develop the achievement of IIS in education. Therefore, this school has done cooperation with other institutions so that there are many places to familiarize the students with their potentials.

The structure of organization of IIS Kediri that interconnects between the local, national and international aspects is presented in Table 1.

Table C.1 The structure of organization of IIS

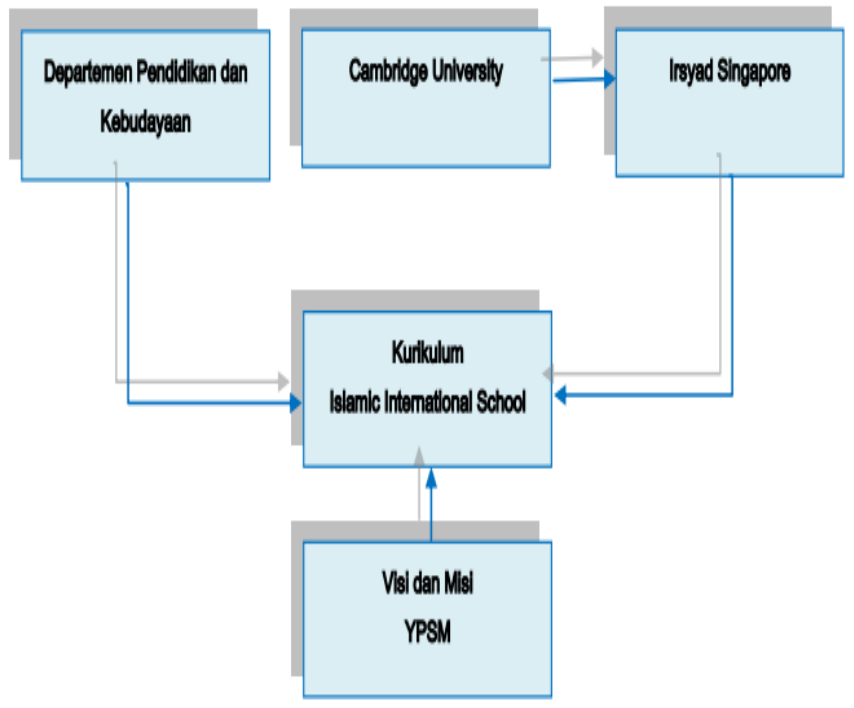

Table C.1 portrays that IIS Kediri does not stand alone. It uses other educational institutions to be sister school as the requirement of internalization. It means that the curriculum in this school comprises the local, national and international curricula. The integration is done by integrating vision and mission of foundation of Sabilul Muttaqien as the local content, the curriculum issued by the department of education and culture, and the curriculum of Cambridge that has been applied by al-Irsyad school of Singapore.

By so doing, IIS Kediri also divides four departments to cater all curricula, comprising departments of math-science, language and humanities, al-Qur'an and Islamic studies, and Information Computer and Technology. The integration of scientific, social, and technology

Vol. 9 No. 2, Juni 2017

Madrasah homepage: http://ejournal.uin-malang.ac.id/index.php/madrasah/index 


\section{MADRASAH}

Jurnal Pendidikan dan Pembelajaran Dasar

p ISSN: 1979-5599 | e ISSN: 2502-194X

P a g e

175

fully portrays that IIS combines the local and global knowledge for the advancement of Islamic primary education and the preparation for young learners to compete in this rapidly changing era.

\section{Three Kernels of IIS as Educational Institutions}

The glocalization can be investigated from its jargons and the practice of those jargons, including three noble kernels related to the bi'ah Islamiyah (familiarization of Islamic culture at school), international branding, and English as working language that can be explored as follows:

a. Bi'ah al-Islamiyah (the familiarization of Islamic culture). This priority is focused on how to make the students familiarize themselves with the Islamic cultures, norms and traditions. The students are used to attending at school at $6.30 \mathrm{a} . \mathrm{m}$ for morning activities that are started by praying together, ma'tsurat (reading surah-surah of al-Qur'an and juz amma), and followed by ice-breaking on science, mathematics, Islamic materials, and short conversation in English or Arabic language everyday as scheduled by the school. Praying dhuha, and praying jama'ah followed by public speaking are also familiarized in this school.

b. International Branding. The international branding is focused on literacy skill that is thematically arranged in the forms of reading, writing, and listening in the first stage. The following stage centers on reading and listening comprehension while understanding the implied meaning of the materials. The themes of the international branding contain science, religion, language that is proportionally in accordance with the life skill as the primary learning target.

c. English as Working Language. English as an international language is purposively functioned by IIS Kediri to support the internationalization because most of developed countries use that language for the communication and business. Simply said, this language is a media for the young learners to gain more knowledge either related to the math-science, Islamic studies, ICT or humanities.

\section{LEARNING METHOD}

In the instructional process, the teachers employed some learning and teaching methods that can foster their creativity such as:

1. Critical and Solutive Thinking. This is focused on how the students can mind map the materials available so as to think and do systematically and creatively.

2. Contextual Learning. This is focused on how the students can understand the materials from the real-life situations. The students can experience hands-on activities with the natives, outdoor classrooms and the use of authentic instructional media that promote local wisdom of traditional games such as dakon, snake and ladder, engklek, layangan, gobak sodor and others that support the materials. Besides, the students can learn not only from the classroom teacher but also from native speaker, academics or other people from various professions that are specially invited by IIS to be guest speaker, such as police man, police woman, doctor, journalist, judge etc. Furthermore, the teacher of Islamic subject said that the students are introduced to pray the Islamic scholars who had thoroughly contributed to the Islamic spread in Indonesia.

Vol. 9 No. 2, Juni 2017

Madrasah homepage: http://ejournal.uin-malang.ac.id/index.php/madrasah/index 
3. Student is Subject of Learning. In this part, the students in the primary 1 actively learn together either in group or individual with the various materials. In this part, the teacher performs as mediator.

4. Inquiry based Learning. This is focused on scientific method. The students on primary 2 observe, analyze and report the natural or social phenomena they perceive.

5. Fun Learning. In this part, the students are guided on how to actively and communicatively learn so as to train their brains in the form of how to improve their linguistic skills and other multiple intelligences to receive messages.

\section{The Learning Target on Academics and Character Aspects}

To meet the targets of academic and character aspects, IIS Kediri has provided miscellaneous programs that center on three priorities of bi'ah al-Islamiyah, international branding and English as working language. The academic programs include SPARKLING IIS, Spelling Bee contest, Al khitobah al Arabiyah, Sceince Day, Market Day, performance for each extracurricular program, graduation Kindergarten. In addition, the non-academic programs that support the leadership consist of Leadership: Inquirers, Knowledgeable, Thinkers, Communicators, Principled, Open-minded, Caring Risk-takers Balanced, Reflective). The best students will obtain a nomination of Khalifah Fil Ardh of the year.

Other programs that can internalize the spirit of nationalism and the sense of belonging is Try and Error and Science Garden. In this occasion, the student will learn how to innovatively love the environment and try to apply theoretical concept of science. To balance it with social competence, the students learn how to be public speakers.

\section{Fostering Global Competence for Teachers}

The teacher professionalism on teaching the students at IIS is frequently fostered. The teachers usually obtain mentorship, namely induction program before they teach or in the first week of their teaching. They are also recommended to have a time for sharing materials and arranging instructional media before teaching. The teachers are highly supposed to learn from references and videos about IIS Kedir so as to comprehend the vision and missions of the institutions they are working at. By so doing, the teachers have a bright understanding and unite their vision and missions of their intentions to teach and develop their working place.

The teachers' competences are also evaluated every year by the school sister from Singapore in the part of teaching performance and English language skills. The annual evaluation of IIS teachers are objective in which when the teachers do not meet the requirement of professional teachers, they have to resign in honor. Therefore, the teachers frequently accomplish educational refreshments like workshop or English program to upgrade their knowledge in teaching and language competence.

\section{E. DISCUSSIONS}

Internationalization interest is inextricable from globalization not only in Islamic higher education but also Islamic primary education, one of which is Islamic International School (IIS). This school has promoted the new concept on instructional practices in the primary classrooms that balance the values at pesantren and the global skills as a refurbishment to attain the quality enhancement, known as glocalization that abstracts the voice of secularism.

The IIS ways are much wider done at industrial boundaries. Take example the film industry of Bollywood that connects India and western cultures. The Bollywood movie makes over itself by employing English, western clothing, musical styles and the story plots

Vol. 9 No. 2, Juni 2017

Madrasah homepage: http://ejournal.uin-malang.ac.id/index.php/madrasah/index 


\section{MADRASAH}

Jurnal Pendidikan dan Pembelajaran Dasar

p ISSN: 1979-5599 | e ISSN: 2502-194X

P a g e

(Rao, 2010). However, the goal of IIS tends to educate the students rather than what movie industries do to their goals on profit-oriented. IIS foci are how to give students and teachers global competence to succeed in facing the waves of globalization effects such as moral degradations, serious disputes among religions or communities, and other social opaque. Simply argued, global competence is crucial skills to be mastered by both the students and teachers in this century.

Cited from Mansilla \& Jackson (2011) at Koziol (2011) shows the recent report, Educating for Global Competence: Preparing our Youth to Engage the World, sponsored by the Asia Society and Council of Chief State School Officers (CCSSO), argued that to be globally competent, all students should be able to:

1. Investigate the world beyond their immediate environment, framing significant problems and conducting well-crafted and age-appropriate research.

2. Recognize perspectives, others' and their own, articulating and explaining such perspectives thoughtfully and respectfully.

3. Communicate ideas effectively with diverse audiences, bridging geographic, linguistic, ideological, and cultural barriers.

4. Take action to improve conditions, viewing themselves as players in the world and participating reflectively.

Analyzed from the findings, this school basically represents the components of internationalizations in Islamic primary school due to its practices of sister school for institution and teacher evaluations, the use of materials that embed local wisdoms and global competence, the utility of ICT for the students and the teachers, the familiarization of international language, and other programs that prepare the students to survive in globalization (Koziol, 2011).

Additionally, IIS is trying to push how students attractively exhibit global and local knowledge through student-centered ways so that the students are not restricted in the little box of small community but strong networking under the same umbrella that is Islam. The networking has been used by establishing the international branding so as to globally attract the students. Teasdale (1997) acknowledges the tensions and discontinuities between the local and the global and suggests searching for a new way of synchronizing or blending the diverse cultures of knowledge in order to equip students with skills for the modern world.

Thus, the notion of incorporating local and global values in educating the young learners is one of strategic efforts by Islamic institutions to make the bad good and the good better to maintain its educational systems in the midst of Indonesia changing curriculum and the regulation in school management and instructional process. The glocalization is also an offer to comprehend and strengthen the community's needs and development. Marhayani (2016) states that local wisdom in the society is one of the material should be contained in character education in which it can develop the cultural values of the society. This understanding is actually not separated from education as a process of inheritance of cultural values of one society to the next generation. Luk-Fong (2005) in (Tien \& Talley, 2012) uses the development of a guidance curriculum in a Hong Kong university as an example of a mix of 'east' and 'west', or as a representation of globalisation-localization enmeshed.

Furthermore local wisdom as an essential part in glocalization is a form of wisdom that exists in certain areas, it has been used for generations as one means to build social

Vol. 9 No. 2, Juni 2017

Madrasah homepage: http://ejournal.uin-malang.ac.id/index.php/madrasah/index 
stability (Firdausia, 2017). Therefore, the value of local wisdom becomes a part of the rules applied in certain groups of society in order to achieve social welfare and justice. Knowing local wisdom can share the students on how to understand local knowledge. Local knowledge is the knowledge that has been tested valid in a local context and accumulated by the local community or people (Cheng, 2002).

As the newly built international Islamic primary school in Kediri, there should be any highlight to improve the institution quality in the part of the integration of curriculum that connect some values, the effectiveness to gauge the students and teachers competences, the affordable prices for the tuition fee and the effectiveness of time allotment for every subject. Besides, the effect of hiring the teachers who do not completely fulfill the requirement of the school needs any deeper study since IIS should firstly consider how to construct the sense of belonging for the teachers to the school dedication. Then, when IIS carries the international branding, there should be certain cooperation that can enrich the global competence of the students and the teachers. It can be the program of students' or teachers' exchanges because when the students are homogenous, it can be contrast with the international brands that prioritize heterogeneity to communicate and get involved in the variety of networking. Seeing this, the terms glocal and glocalization are not new and have mainly been associated with the business, technology, and sociology disciplines (Patel \& Lynch, 2013).

To the end of this discussion, it can be said that IIS portraying spirit of Sabilul Muttaqien pesantren can be one of clear miniatures that sustainably innovates the Islamic educational practice in the midst of the globally changing era that has contemporary curriculum designs and the rules on instructional implementations. IIS has exhibited the local wisdom and global knowledge that is essential for adjusting young generations with world dynamics. It can be seen from the instructional practices that are similar to the pesantren. The concepts of education in IIS explicates the instructional methods in pesantren that are believed to be effective to produce students who are skilful, socially influential and good moral. Those methods include Sorogan, Wetonan or Halaqah and mentoring that are generated from the local wisdom. The sorogan and wetonan are effective to produce highly disciplined, obedient and passionate students (Kuswandono et al, 2011). In IIS, those are mostly applied in most of lessons in social and natural science.

\section{F. CONCLUSIONS}

The concern on glocalization can be the best choice for the Islamic primary schools in Indonesia. The glocalization does not neglect the social norms and shared beliefs that have been constructed by society because they insert the local identity and heritage to master global knowledge and save local identity. The students can be prepared to engage in global circle by maintaining their local identity that protects their demeanors as Indonesia Muslims who are civilized. More people have become more competitive to adjust themselves along the time in globalization era. It is questionable whether the students can embrace this fluctuation of globalization. Accordingly, education can seriously answer this condition by setting the curriculum that intertwines global and local knowledge. In brief, internationalization that is about "think globally and act locally" can prepare the students on their era since the golden age or child age.

\section{Acknowledgments}

We greatly thank to Bapak Budi Setyo Margono, M.Pd, a smart and cooperative principal of Islamic International School (IIS) Kediri for the kind permission and helps. Big bouquets are also sent to all of teachers and staffs of IIS Kediri that nicely tell us what IIS is.

Vol. 9 No. 2, Juni 2017

Madrasah homepage: http://ejournal.uin-malang.ac.id/index.php/madrasah/index 


\section{MADRASAH}

Jurnal Pendidikan dan Pembelajaran Dasar

p ISSN: 1979-5599 | e ISSN: 2502-194X

P a g e

179

Then, it is a great thank for Religious Ministry Affair of Republic Indonesia (Kemenag RI) that has given enormous support and appreciation to let this paper presented at AICIS XVI.

\section{REFERENCES}

Blackmore, J. (1999). Localization/ Globalization and the Midwife State: Strategic Dilemmas for State Feminism in Education? J. of Education Policy, 14(1), 33-54

Boyd, D. (2006). Glocalization: When Global Information and Local Interaction Collide. Talk presented at the O'Reilly Emerging Technology Conference, San Diego, CA. Retrieved from http://www.danah.org/

Carnoy, M. (2005). Globalization, Educational Trends and the Open Society. A Paper Presented at OSI Education Conference 2005: "Education and Open Society: A Critical Look at New Prespectives and Demands".

Cheng, Yin. Cheong. (2002). Fostering Local Knowledge and Wisdom in Globalized Education: Multiple Theories. Presented at The 8th International Conference on "Globalization and Localization Enmeshed: Searching for a Balance in Education on November 18-21, 2002 in Thailand

Clarke, J. (2002). Childhood and Children. Blackwell Publishing. Assessed from http:/ / www.blackwellpublishing.com/

Douglass, J. A. (2005) All Globalization Is Local: Countervailing Forces and the Influence on Higher Education Markets. Research \& Occasional Paper Series: CSHE.1.05.

French, G. (2007). Children's early learning and development A research paper. the National Council for Curriculum and Assessment (NCCA). 24 Merrion Square, Dublin 2 http:/ / www.ncca.ie/

Mungmachon, R. (2012). Knowledge and Local Wisdom: Community Treasure. International Journal of Humanities and Social Science, 2(13): 174-181

Khondker, H. H. (2004). Glocalization as Globalization: Evolution of a Sociological Concept. Bangladesh e-Journal of Sociology, 1(2). Retrieved from http://muktomona.net/Articles/habibul_haque/Globalization.pdf

Koizol, S et al. (2011). Internationalizing Teacher Education: A Systemic Initiative. College of Education University of Maryland U.S.A. International Conference on Education for Teaching Glasgow, Scotland

Kuswandono, P et al. (2011). Revisiting Local Wisdom: Efforts to Improve Education Quality in Indonesia. Proceeding. AARE Annual Conference Hobart

Li Ping Wang \& Hsuan-Fu Ho. (2012). Internationalization versus Localization: The Case of Primary Education in Taiwan. International Education Studies, 5(4): 39-4

Luk-Fong, P. Y. Y. (2005). Globalization and Localization Enmeshed - towards a Framework for the Development of Guidance Curriculum in Hong Kong. Globalization, Societies and Education, 3(1), 83-100

Marhayani, Dina, Anika. (2016). Development of Character Education Based on Local Wisdom in Indigenous People Tengahan Sedangagung. Journal of Education, Teaching and Learning, 1(2): 66-70

Pillania. Rajesh K. (2012). The Globalization of Indian Hindi Movie Industry, Management 3 (2): 115-123

Vol. 9 No. 2, Juni 2017

Madrasah homepage: http://ejournal.uin-malang.ac.id/index.php/madrasah/index 
Rao, S. (2010). I Need an Indian Touch: Glocalization and Bollywood Films, Journal of International and Intercultural Communication, 3(1): 1-19

Schröttner, B. T. (2010). The Effects of Globalization Phenomena on Educational Concepts. US-China Education Review, 7(8), 50- 61

Teasdale, G. R. (1997). Globalisation, Localization: Impacts and Implications for Teacher Education in the Asia-Pacific Region. (ERIC Document Reproduction Service No. EJ $416038)$.

Tien, Ching-Yi \& Talley, Paul C. (2012). Think Globally, Act Locally: Glocalization in Taiwanese Higher Education. International Journal of Business and Social Science, 3(15); August 2012

Tong, H. K. \& Cheung, L. H. (2011). Cultural Identity and Language: A Proposed Framework for Cultural Globalization and Glocalisation. Journal of Multilingual and Multicultural Development, 32 (1), 55-69

Warner, Chantelle. (2011). Rethinking the Role of Language Study in Internationalizing Higher Education Journal Issue: L2 Journal, 3(1). University of Arizona

Welikala, T. (2011). Rethinking International Higher Education Curriculum: Mapping the Research Landscape. Nottingham, UK: Universitas 21. Publication. http:/ / escholarship.org/

Zakaria, G. A. N. (2010). Pondok Pesantren: Changes and Its Future. Journal of Islamic and Arabic Education. 2(2): 45-52

\section{Some Sources:}

1. http://www.glocalforum.org/

2. http://www.tandfonline.com/journal_of_international_and_intercultural_communi cation

3. http://www.researchgate.net//publication/228276224_globalization_to_glocalizatio n_A_conceptual_analysis

4. http://www.iispsm.sch.id/

5. http://ypipsm.or.id/

Vol. 9 No. 2, Juni 2017

Madrasah homepage: http://ejournal.uin-malang.ac.id/index.php/madrasah/index 